\title{
Phytochemical Screening and Evaluation of the Effects of Methanolic and Ethanolic Extracts of Jatropha curcas and Chlorophora excelsa on Candida albicans and Staphylococcus aureus
}

\author{
C. Mbakwem-Aniebo*, A.U. Osadebe and S.E. Obi \\ Department of Microbiology, University of Port Harcourt, P.M.B. 5323, Choba, Nigeria \\ *Corresponding author
}

\begin{tabular}{|c|c|}
\hline & A B S T R A C T \\
\hline $\begin{array}{l}\text { Ke e y w or d s } \\
\text { Jatropha curcas, } \\
\text { Chlorophora } \\
\text { excelsa, } \\
\text { Phytochemicals, } \\
\text { Medicinal Plants, } \\
\text { Candida albicans, } \\
\text { Staphylococcus } \\
\text { aureus }\end{array}$ & \multirow{3}{*}{$\begin{array}{l}\text { The } 80 \% \text { methanolic and ethanolic extracts of the dried leaves of Jatropha curcas } \\
\text { were subjected to phytochemical and antimicrobial sensitivity screening. The } \\
\text { phytochemical screening for the methanolic extract revealed the presence of } \\
\text { alkaloids, tannins, saponins, flavonoids and cardiac glycosides while the ethanolic } \\
\text { extract revealed the presence of alkaloids, tannins, saponins, flavonoids, } \\
\text { anthraquninones and combined anthraquinones. The phytochemical screening of } \\
\text { the methanolic extract of Chlorophora excelsa also revealed the presence of the } \\
\text { above metabolites found in J. curcas excluding the cardiac glycosides whilst the } \\
\text { phytochemical screening of the ethanolic extract revealed the presence of } \\
\text { alkaloids, tannins, saponins and flavonoids. The antimicrobial activity of both leaf } \\
\text { extracts were independently assessed using clinical isolates of Candida albicans } \\
\text { and Staphylococcus aureus. The techniques used were the well-in-agar diffusion } \\
\text { and agar dilution methods which showed that the leaves were active against } \\
\text { Staphylococcus aureus but not against Candida albicans. }\end{array}$} \\
\hline Article Info & \\
\hline & \\
\hline
\end{tabular}

\section{Introduction}

The use of medicinal plants for the treatment of various conditions has persisted amongst African tribes for generations. It could be deemed the oldest form of health care management. Successive generations across the continent still rely chiefly on herbal medicines. The WHO (2005) maintains that traditional medicine serves the health needs of a large portion of the world's population especially in the rural areas of developing countries. In many parts of Africa, herbal medicine still plays a vital role in health care delivery systems especially in remote areas where clinics and hospitals are sparsely located. In these communities, traditional herbalists operate closer to the people, taking advantage of the biodiversity of plant species in such areas to manage various diseases and aliments (Zuma et al., 2016; Mahamoodally, 2013, Payyappallimana, 2010). The need for more cost effective, easily accessible alternative therapeutic options to currently used antibiotics which are becoming increasingly ineffective against hitherto susceptible bacteria cannot be overemphasized. Medicinal plants fit the criteria. 
Jatropha curcas, commonly known as physic nut, purging nut, Barbados nut or pig nut, has been used in traditional medicine for several generations to treat various health conditions including tumours, fever, jaundice, rheumatism, mouth infections and guinea worm sores (Rampadarath, 2016, Arekemase et al., 2011, Arun et al., 2013). Members of the rural communities of India have been known to use the herb in the treatment of dysentery and colic (Kalimuthu et al., 2010). Its antimicrobial effects have been compared to those of Gentamycin by Dada et al., (2014). Chlorophora excelsa is the tree popularly known as 'iroko'; its extracts have been used for wound healing as well as the treatment of cough, fever, backache, toothache, hepatitis and oedema (Udegbunam et al., 2013, Ndenecho, 2009).

This study seeks to evaluate the antimicrobial activity of the $80 \%$ methanolic and ethanolic extracts of the dried leaves of Jatropha curcas and Chlorophora excelsa using the same extraction method, solvent concentration, test bacteria and susceptibility testing methods via agar dilution and agar diffusion techniques.

\section{Materials and Methods}

Fresh leaves of Jatropha curcas and Chlorophora excelsa collected in the month of September from the Botanical garden of the University of Port Harcourt, Rivers State, Nigeria were sorted out and dried at room temperature protected from sunlight. Botanical identification was carried out in the herbarium unit of the Department of Plant Science and Biotechnology, University of Port Harcourt.

Separate samples consisting of $82.9 \mathrm{~g}$ each of crushed air-dried leaves of Chlorophora excels were soaked in methanol and ethanol for 72 hours. For Jatropha curcas, $85 \mathrm{~g}$ samples were used. The respective samples were then filtered using Whatmann no. 1 filter paper and the filtrates (crude extracts) were separately put through a rotary evaporator and concentrated to dryness in a water bath at $40 \mathrm{oC}$ to give a constant weight. The presence or absence of alkaloids, tannins, phlobatannins, saponin, flavonoids, anthraquinones (free and combined) and cardiac glycosides were determined according to the methods of Trease and Evans (1989) and Sofowora (2008).

The clinical isolates of Candida albicans and Staphylococcus aureus were identified and characterised using morphological, Gram staining and biochemical tests. MacFarland standard (0.5) was used to standardize the test organisms. A stock solution of $500 \mathrm{mg} / \mathrm{ml}$, from which concentrations of $250 \mathrm{mg} / \mathrm{ml}$, $125 \mathrm{mg} / \mathrm{ml}, \quad 62.5 \mathrm{mg} / \mathrm{ml}, \quad 31.25 \mathrm{mg} / \mathrm{ml}$ and $15.624 \mathrm{mg} / \mathrm{ml}$ were made, was prepared for both the methanolic and ethanolic extracts of Chlorophora excelsa and Jatropha curcas.

A24-hour old broth culture of the test organisms (standardized inocula) was swabbed on to Mueller-Hinton agar (MHA) for S. aureus and Sabouraud Dextrose Agar (SDA) for Candida albicans in petri dishes using sterile cotton swabs. A sterile stainless steel $6 \mathrm{~mm}$ diameter cork borer was used to create uniform wells in the agar. Each of the five different concentrations of the relevant extract was put in the wells and labeled appropriately. The Mueller-Hinton agar seeded with bacteria was incubated at $37^{\circ} \mathrm{C}$ for 24 hours. Control plates containing sterile distilled water in the wells were made in parallel.

For the Agal dilution test, $1 \mathrm{ml}$ of reconstituted extract of the different concentrations were added to different petri dishes having sterile 9ml Mueller-Hinton agar (MHA) for S. aureus and Sabouraud Dextrose Agar (SDA) for $C$. albicans. The agar plates 
were prepared in duplicates and allowed to set at room temperature. The standardized culture was then aseptically inoculated unto the agar using the spread plate technique. Incubation was at $37 \mathrm{oC}$ for 24 hours. Control plates comprising inocula without the extracts were made in parallel (Collins et al., 1995).

\section{Results and Discussion}

The methanolic extract of $J$. curcas contained alkaloids, tannins, saponin, flavonoids, combined anthraquinones and cardiac glycoside with high concentrations of tannins. The ethanolic extract contained similar phytochemicals but had a higher concentration of saponins. With C. excelsa, the methanolic extract contained alkaloids, tannins, saponin, flavonoid and combined anthraquinones while the ethanolic extract contained alkaloids, tannins, saponin, flavonoids, combined anthraquinones and cardiac glycoside. The ethanolic extract contained higher concentrations of flavonoids than the methanolic extract (Table 1).

With the susceptibility tests, a clear zone of inhibition indicates antimicrobial activity against the test organism while the absence of this zone of inhibition is indicative of resistance. Neither the ethanolic nor methanolic extracts of either plant affected the growth of Candida albicans but zones of inhibition of growth were observed with Staphylococcus aureus for both the ethanolic and methanolic extracts of both plants (shown in Tables 2-5).

Table.1 Phytochemical screening of methanoilicand ethanolic extracts of $J$. curcas and C. excelsa

\begin{tabular}{|c|c|c|c|c|}
\hline \multirow[b]{2}{*}{ Phytochemical } & \multicolumn{2}{|c|}{ Jatropha curcas } & \multicolumn{2}{|c|}{ Chlorophora excelsa } \\
\hline & $\begin{array}{l}\text { Methanoilic } \\
\text { Extract }\end{array}$ & $\begin{array}{l}\text { Ethanoilic } \\
\text { Extract }\end{array}$ & $\begin{array}{c}\text { Methanoilic } \\
\text { Extract }\end{array}$ & $\begin{array}{l}\text { Ethanoilic } \\
\text { Extract }\end{array}$ \\
\hline Alkaloids & + & ++ & + & + \\
\hline Tannins & +++ & ++ & ++ & + \\
\hline Phlobatanins & - & - & - & - \\
\hline Saponin & ++ & +++ & + & + \\
\hline Flavonoids & ++ & + & + & ++ \\
\hline Anthraquinones & - & + & ++ & + \\
\hline Combined & + & + & + & + \\
\hline $\begin{array}{l}\text { Anthraquinones } \\
\text { Cardiac Glycoside }\end{array}$ & & & & \\
\hline - Salkowski Test & + & + & - & + \\
\hline - $\quad$ Liebermann Test & + & - & - & - \\
\hline $\begin{array}{ll}\text { - } & \text { Keller Killiani } \\
\text { Test } & \end{array}$ & - & + & - & - \\
\hline
\end{tabular}

KEY: +++ Highly present, ++ $\quad$ Moderately present, + Present, - Absent 
Table.2 Antimicrobial activity of the methanolicand ethanolic extracts of J. curcas using the agar dilution method

\begin{tabular}{|c|c|c|c|c|}
\hline \multirow{2}{*}{$\begin{array}{l}\text { Concentrations of extract } \\
\text { incorporated in MHA for } \\
\text { S.aureus and SDA for C.albicans } \\
(\mathrm{mg} / \mathrm{ml})\end{array}$} & \multicolumn{2}{|c|}{ Methanolic Extract } & \multicolumn{2}{|c|}{ Ethanolic Extract } \\
\hline & $\begin{array}{c}\text { Staphylococcus } \\
\text { aureus }\end{array}$ & $\begin{array}{l}\text { Candida } \\
\text { albicans }\end{array}$ & $\begin{array}{c}\text { Staphylococcus } \\
\text { aureus }\end{array}$ & $\begin{array}{l}\text { Candida } \\
\text { albicans }\end{array}$ \\
\hline 500.00 & - & + & - & + \\
\hline 250.00 & - & + & - & + \\
\hline 125.00 & - & + & - & + \\
\hline 62.50 & + & + & + & + \\
\hline 31.25 & + & + & + & + \\
\hline 15.625 & + & + & + & + \\
\hline Control & + & + & + & + \\
\hline
\end{tabular}

Table.3 Antimicrobial activity of the methanolic and ethanolic extracts of C. excelsa using the agar dilution method

\begin{tabular}{|c|c|c|c|c|}
\hline \multirow{2}{*}{$\begin{array}{l}\text { Concentrations of extract } \\
\text { incorporated in MHA for S.aureus } \\
\text { and SDA for C.albicans }(\mathrm{mg} / \mathrm{ml})\end{array}$} & \multicolumn{2}{|c|}{ Methanolic Extract } & \multicolumn{2}{|c|}{ Ethanolic Extract } \\
\hline & $\begin{array}{c}\text { Staphylococcus } \\
\text { aureus }\end{array}$ & $\begin{array}{l}\text { Candida } \\
\text { albicans }\end{array}$ & $\begin{array}{c}\text { Staphylococcus } \\
\text { aureus }\end{array}$ & $\begin{array}{l}\text { Candida } \\
\text { albicans }\end{array}$ \\
\hline 500.00 & - & + & - & + \\
\hline 250.00 & - & + & - & + \\
\hline 125.00 & - & + & - & + \\
\hline 62.50 & + & + & + & + \\
\hline 31.25 & + & + & + & + \\
\hline 15.625 & + & + & + & + \\
\hline Control & + & + & + & + \\
\hline
\end{tabular}

KEY: +: Growth $\quad-$ : No Growth

Table.4 Diameter of zones of inhibition $(\mathrm{mm})$ in susceptibility test of the methanolic and ethanolic extracts of $J$. curcas using the well in agar diffusion method

\begin{tabular}{ccccc}
\hline $\begin{array}{l}\text { Concentrations of extract } \\
\text { incorporated in MHA for S.aureus } \\
\text { and SDA for C.albicans }(\mathrm{mg} / \mathrm{ml})\end{array}$ & $\begin{array}{c}\text { Methanolic Extract } \\
\text { Staphlococcus } \\
\text { aureus }\end{array}$ & $\begin{array}{c}\text { Candida } \\
\text { albicans }\end{array}$ & $\begin{array}{c}\text { Ethanolic Extract } \\
\text { Staphylococcus } \\
\text { aureus }\end{array}$ & $\begin{array}{c}\text { Candida } \\
\text { albicans }\end{array}$ \\
\hline 500.00 & $11 \pm 0.1$ & - & $13 \pm 0.2$ & - \\
250.00 & $10 \pm 0.2$ & - & $14 \pm 0.1$ & - \\
125.00 & $10 \pm 0.1$ & - & $12 \pm 0.2$ & - \\
62.50 & - & - & - & - \\
31.25 & - & - & - & - \\
15.625 & - & - & - & - \\
Control & - & - & - & - \\
\hline
\end{tabular}


Table.5 Diameter of zones of inhibition $(\mathrm{mm})$ in susceptibility test of the methanolic and ethanolic extracts of $C$. excelsa using the well-in-agar diffusion method

\begin{tabular}{lcccc}
\hline $\begin{array}{l}\text { Concentrations of extract } \\
\text { incorporated in MHA for } \\
\begin{array}{l}\text { S.aureus and SDA for } \\
\text { C.albicans }(\mathrm{mg} / \mathrm{ml})\end{array}\end{array}$ & $\begin{array}{c}\text { Methanolic Extract } \\
\text { Staureus }\end{array}$ & $\begin{array}{l}\text { Candida } \\
\text { albicans }\end{array}$ & $\begin{array}{l}\text { Ethaphylococcus } \\
\text { aureus }\end{array}$ & $\begin{array}{c}\text { Extract } \\
\text { Candida } \\
\text { albicans }\end{array}$ \\
\hline 500.00 & $10 \pm 0.1$ & - & $11 \pm 0.1$ & - \\
250.00 & $10 \pm 0.2$ & - & $10 \pm 0.2$ & - \\
125.00 & $10 \pm 0.1$ & - & $10 \pm 0.1$ & - \\
62.50 & - & - & - & - \\
31.25 & - & - & - & - \\
15.625 & - & - & - & - \\
Control & - & - & - & - \\
\hline
\end{tabular}

KEY: No zone of inhibition

The methanolic and ethanolic extracts of the leaves of both plants had inhibitory effects on Staphylococcus aureus at concentrations of $125 \mathrm{mg} / \mathrm{ml}$ and higher but had no effect on the growth of Candida albicans. At lower concentrations (less than $125 \mathrm{mg} / \mathrm{ml}$ ), there was no inhibitory effect on either microorganism. This is similar to the results obtained by Igbinosa et al., (2009) and Rampadarath et al., (2016) who indicated that the extracts of Jatropha curcas inhibited the growth of Staphylococcus aureus. A study by Chime et al., (2011) also confirms the inhibitory effect of the methanolic extract of C. excelsa against S. aureus. Similarly, Padayachee and Odhav (2013) agree that the growth of Staphylococcus sp. is inhibited by extracts of $C$. exclesa. These findings are somewhat in contrast to the conclusions drawn by Arun et al., (2013) who inferred that neither the methanolic nor ethanolic extracts of the latex of $J$. curcas affected the growth of S. aureus. Arekemase et al., (2011) on the other hand, found extracts of J. curcas to be effective against both $\mathrm{S}$. aureus and C.albicans. Clearly, the inhibitory effects of the plant extract are largely dependent on the concentration, parts of the plant used and the microorganisms involved (Kalimuthu et al., 2010).
Based on the inhibitory effects of the ethanolic and methanolic extracts of the leaves of Jatropha curcas and Chlorophora excels in this study, both plants can be used in the treatment of ailments caused by Staphylococcus aureus provided there are no side effects.

It is concluded that Methanol and ethanol are efficient in extracting alkaloids, tannins, saponins, flavonoids and anthraquinones present in the dried leaves of both Jatropha curcas and Chlorophora excelsa. This study indicates that the methanolic and ethanolic extracts of Jatropha curcas and Chlorophora excelsa were active against Staphylococcus aureus but inactive against Candida albicans.

\section{References}

Arekemase, M. O., Kayode, R. M. O. and Ajiboye, A. E. (2011) Antimicrobial Activity and Phytochemical Analysis of $J$. curcas Plant against some Selected Microorganisms. International Journal of Biology 3(3): $52-59$.

Arun, K., Bharwaj, A. and Ruchika, G. (2013) A Comparative Study of Antibacterial Activity of Leaves and Latex of Jatropha curcas L. International Journal of Pharmacy and Pharmacology 4(4): 190 - 194. 
Chime, C. C., Okorie, I. A., Ekanem, E. J. and Kagbu, J. A. (2011) Analysis and Remediation of Faecal Coliform Bacteria Pollution in Selected Surface Water Bodies of Enugu State, Nigeria. World Academy of Science, Engineering and Technology 56: $1565-1570$.

Collins, C. H.; Lynes, P. M. and Grange, J. M. (1995) Microbiological Methods. 7th Ed. Butterwort-Heinemann Ltd., United Kingdom.

Dada,E. O.,Ekundayo, F. O. and Makanjuola, O. O. (2014) Antibacterial Activities of Jatrophacurcason Coliforms isolated from Surface Waters in Akure, Nigeria. International Journal of Biomedical Science 10(1): $25-30$.

Igbinosa, O. O., Igbinosa, E. O. and Aiyegoro, O. A. (2009) Antimicrobial Activity and Phytochemical Screening of Stem and Bark Extracts from Jatropha curcas. African Journal of Pharmacy and Pharmocology 3(2): $058-062$.

Kalimuthu, K., Vijayakumar, S. and Senthilkumar, R. (2010) Antimicrobial Activity of Biodiesel Plant,Jatropha curcas. International Journal of Pharmacy and Pharmacology 1(3): 1- 5.

Mahamoodally, M. F. (2013) Traditional Medicines in Africa: An Appraisal of Ten Potent African Medicinal Plants. Evidencebased Complementary and Alternative Medicines 2013: Article ID 617459.

Ndenecho, E. N. (2009) Herbarium and resources for the development of ethnopharmacology in Mount Cameroon region. African Journal of Pharmacy and Pharmacology 3(3): 78 86.
Padayachee, T. and Odhav, B. (2013) Antimicrobial activity of plant phenols from Chlorophora excelsa and Virgilliaoroboides. African Journal of Biotechnology 12(17): 2254 - 2261.

Payyappallimana, U. (2010) Role of Traditional Medicine in Primary Healthcare: An Overview of Perspectives and Challenges. Yokohama Journal of Social Sciences 14(6): $57-77$.

Rampadarath, S., Puchova, D. and Jeewon, R. (2016) Jatropha curcas L.: Phytochemical, Antimicrobial and Larvicidal Properties. Asian Pacific Journal of Tropical Biomedicine 6(10): 858 - 865 .

Sofowora, A. (2008) Medicinal plants and traditional medicine in Africa. 3rd Ed. Spectrum Books, Ibadan.

Trease, G.E. and Evans, W. C. (1989)Pharmacognosy. 13th Ed. Bailliere Tindall, London, UK. pp.345 - 346, 535 $536,772-773$.

Udegbunam, S. O., Nnaji, T. O., Udegbunam, R. I., Okafor, J. C. and Agbo, I. (2013) Evaluation of Herbal Ointment Formulation of Miliciaexcelsa (Welw.) C. C. Berg. for Wound Healing. African Journal of Biotechnology 12(21): 3351 - 3359 .

World Health Organisation (2005) General Guidelines for Methodologies on Research and Evaluation of Traditional Medicine. WHO, Geneva.

Zuma, T., Wight, D., Rochat, T. and Moshabela, M. (2016) Role of Traditional Health Practitioners in Rural Kwazulu-Natal, South Africa: Generic or Mode Specific. BMC Complementary and Alternative Medicine, 16(1): $1-13$.

\section{How to cite this article:}

Mbakwem-Aniebo, C., A.U. Osadebe and Obi, S.E. 2017. Phytochemical Screening and Evaluation of the Effects of Methanolic and Ethanolic Extracts of Jatropha curcas and Chlorophora excelsa on Candida albicans and Staphylococcus aureus. Int.J.Curr.Microbiol.App.Sci. 6(5): 1883-1888. doi: https://doi.org/10.20546/ijcmas.2017.605.208 